\title{
Women Convict Hopelessness: Challenges for Service Guidance and Counseling
}

\author{
Indah Sukma Wati \\ Department of Counseling and Guidance \\ Universitas Negeri Padang, Indonesia \\ indahsukmawati@fip.unp.ac.id \\ Zikra Zikra \\ Department of Counseling and Guidance \\ Universitas Negeri Padang, Indonesia
}

\author{
Afdal Afdal \\ Department of Counseling and Guidance \\ Universitas Negeri Padang, Indonesia \\ afdal@konselor.org \\ Rina Trisna \\ Department of Counseling and Guidance \\ Universitas Negeri Padang, Indonesia
}

\author{
Wiwin Andriani \\ Department of Counseling and Guidance \\ Universitas Negeri Padang, Indonesia
}

\begin{abstract}
Women who commit crimes will be given a sentence of imprisonment, while in prison will experience situations of hopelessness such as not wanting to communicate, closing themselves in the environment, being depressed, deep sadness and other psychological disorders. This condition requires intervention from the counselor through guidance and counseling services. The purpose of writing this article is to discuss in more detail of the concepts of hopelessness in female prisoners which are linked to the possibility of intervention guidance and counseling. Data was collected through library studies regarding hopelessness and possible guidance and counseling services.
\end{abstract}

Keywords: hopelessness, women convict, guidance and counseling

\section{INTRODUCTION}

The more time is developing, human needs are increasing. Therefore, there are many people today who cannot keep up with the times, so they are wrong to take steps to meet their needs. The inability of individuals to meet their needs makes them take shortcuts by stealing, robbing, corruption, etc. This behavior is a form of criminality.

Crime is an act that violates the law and social norms so that people oppose it (Kartono, 2011: Lumenta, Kekenusa, Hatidja, Jalur, \& Eksogen, 2009). Sociologically, crime is all forms of speech, deeds, and behavior that are economically, politically, and social psychologically very detrimental to society, violate moral norms and attack the safety of citizens (Kartono, 2003).

Criminal behavior can arise because of various factors that affect it. The main factors that tend to cause criminal behavior or crime are lust and emotions that are not controlled, poverty, low standards of social values, and of course there are still other factors that can also be a trigger for the emergence of criminal acts, which in turn they become prisoners (Puspasari, 2016).

Convicts are individuals who undergo criminal offenses and lose their independence at the level of being a society whose position is weak and unable to compare with the general public who have freedom because inmates will feel the conditions for a certain time where they have limited space for movement by the prison wall. But an inmate remains the one man, only separated for a while from people who would not the legal interests of the criminal (Budiman, 2017).

While in prison, prisoners will begin to feel conditions that are different from their living conditions while in the community, where inmates cannot be free to do the activities they like. Accordingly (Tololiu \& Makalalag, 2015)

states that prison conditions and life changes experienced by inmates cause continuous pressure so that they are unable to change attitudes towards the conditions that must be dealt with and result in inmates losing their meaning in life, he becomes a hopeless person and have no motivation to spend the days that will be spent the rest of his life in prison. The existence of these differences, then the conditions of individuals in dealing with and solving problems also vary, problems, challenges, obstacles in their lives form different behaviors, it is known that there are certain individuals who experience despair, or are in a hopelessness condition.

Despair (hopelessness) describes the state of someone who does not see the possibility that life will increase and maintain that no one could help or do anything for himself (Carpenito, 2013). Meanwhile, hopelessness is a condition that causes stress, the inability of an individual to think about his future, do something meaningful in his life and empower himself (Davison, Johson, Kring, 2013).

The depressed and helpless individual makes him lose hope about the future. Explaining hope also allows one to believe in the future, despair makes people lose their minds to see the vision of the image and foresight about what will happen in the future. Internal factors that affect individual expectations: the threat of autonomy, self-esteem, independence, strength, and integrity. In addition, it also influences external factors such as the existence of individuals to support it and their perceptions 
by individuals the length of life depends on the individual's hopes and despair.

Furthermore, from the various conditions and conditions of individuals who are hopelessness, the role of Guidance and Counseling (BK) is very important in overcoming and preventing the individual from being drawn into the problem..

\section{HOPELESSNESS}

\section{A. Definition of Hopelessness}

Hopelessness defined as a system of the cognitive scheme which is the designation for negative expectations about the future. A belief that the future is frightening and problems faced by fire have no way out (Beck, Weissman, Lester, \& Trexles, 1974). Hopelessness is the lack of hope of an individual to change the pattern of life misery in the future. Individuals consider that a negative life event as a thing that must have occurred and cannot be avoided, while a positive life event is seen as something that will not happen (Nietzel, Speltz, McCauley, \& Bernstein, 1998).

According to Carpenito (2013) hopelessness is different from helplessness. Desperate individuals see no solution or way to achieve what they want and feel controlled while individuals who experience powerlessness can still see alternatives or answers to what they are facing but cannot do anything because of lack of control or resources. When individuals experience feelings of helplessness that can continuously continue to be hopeless.

Despair is related to sadness, depression, and suicide. Individuals who experience despair see no way and lose to change these negative events so that it will affect various areas of life (Dunn, 2005). According to Farran et al, individuals who are aware of or understand the despair they experience will have the potential to develop expectations for the better the situation they face. However, if the individual is not aware of the hopelessness experienced, then there is less opportunity to develop hope to achieve a better situation (Caninsti, 2012).

\section{B. Hopelessness Components}

According to Farran et.al (Caninsti, 2012) despair (hopelessness) is divided into three components, namely : (1) Affective component, this component is a way to feel something, where despair expressed as a feeling of helplessness and emptiness and a feeling demoralized. When a person feels hopeless, he also feels trapped in the situation and feels "his soul is dry and dead; (2) Cognitive component, this component is a way of thinking, where someone who is hopeless will be disrupted. He has difficulty realizing the plans that have been prepared and difficulty in realizing alternative ways to overcome the problem. He also did not believe that others were able to help him to find solutions to the problems faced; (3) Behavioral component means a way of acting, in which the affective and cognitive components of this then affects the way people behave. Desperate individuals generally experience paralysis or an inability to act.

In addition to the above three components, despair can be examined from four attributes. Farran et al
(Caninsti, 2012) namely: the first is Experiential Process, Attributes experiential process means individuals undergo a series of negative life experiences that make him desperate. Here, it is not the experience itself that fully causes a person to become discouraged, but rather because of the number of heavy life events, the ability to interpret them, the personal values that an individual has, and the internal and external resources of an individual in dealing with / resolving life's difficulties. It is important to note, that this attribute is not only related to the experience of loss that is present now but also rooted in the past.

The second attribute is Despair as a Spiritual or Transcendent Process. Spiritual attribute / transcendent process means the diminishing or disappearing of a person's ability to imagine then the help that comes from outside themselves, both God's help or someone else's. Despair experienced by these individuals caused loss of life orientation, giving rise to a sense of pain and feel weak. These individuals are usually also not able to ask for help from others and tend to ridicule communication.

The third attribute is desperation as Irrational Thought Process, Attributes irrational thought process is the absence of a rational response to the loss and difficult life experiences. Rational responses include thoughts about realistic life goals, the presence of adequate selfresources, and appropriate actions, and a realistic level of self-control, as well as pragmatic views about time. If these five components complete one's thought process when facing loss and bitter life experience, then the despair felt by someone is only temporary and will turn into hope/hope. Meanwhile, in people who are unable to think 'straightly' in the five components, despair can be permanent and not even be a pathological threat.

Recently attribute of Relational Process, attribute relational process in despair means individuals are not able to trust others, the individual is difficult to imagine that the other person delivering the excitement and support. Individuals also assume that no one can love and support themselves.

\section{Factors Affecting the Emergence of Hopelessness}

The emergence of a hopeless behavior in a person is influenced by two main factors, namely internal factors and external factors: 1) Internal factors, f internal actors are factors that originate from within a person, which can influence the behavior of despair. Factors influencing include stable and global attribution patterns to negative events. Confidence in the emergence of consequences in the presence of negative events, and beliefs about selfcharacteristics as causes of negative events, depressogenic attribution patterns and standards for situational conditions, (Abramson \& Metalsky, 1989).

There are two kinds of beliefs, namely positive beliefs and negative beliefs. Where these beliefs will greatly affect how much the emergence of despair behavior in someone. 2) External factors, external actors are factors originating from the surrounding environment which can influence the emergence of hopeless behavior. Factors that influence this include social support that can come from family members, such as spouses, children, parents, and relatives. 
According to the theory of despair put forward by (Abramson \& Metalsky, 1989) originated from a negative event (negative live event) which was seen as a very important event. There are also preconditions or other causes that can influence, which will be explained in full as follows: 1) Because of the proximal complement, Despair contains two elements, namely negative expectations towards the realization of expectations (negative outcome expectancy) and a sense of helplessness to be able to change the reality (helplessness expectancy) 2) because, contributing - proximal , factor etymology factor is the cause-proximal contribution to the emergence of despair-depression is: \ global attributions to negative events. The pattern of attribution to negative events is a function of the situational information encountered.

A stable pattern of attribution is defined as a way of looking at information that is permanent in an individual's mindset. global attribution patterns are interpreted as a comprehensive perspective. In the face of negative events arises the assumption that these negative events will affect his entire life. The attribution pattern is accompanied by the level of individual interest in negative events that arise. Second, the belief that negative consequences will arise in the presence of negative events.

This belief is independent of the causal attributions made but opens up opportunities for depression if the event is considered to be very important in life, irreparable, impossible to change and does not affect all aspects of life. Third, beliefs about negative selfcharacteristics as causes of negative events. This belief is inseparable from the causal attributions made and those characterized negatively are self-esteem, ability, and personality. Fourth, lack of social support.

This factor also contributed to triggering the growth of despair and ultimately caused depression. 3) Because contribution - distal, There are two etymological factors which are in this position and affect despair: First, depressogenic thought. Interpreted as a mindset tendency that can lead to depression. Second, the reference to situational conditions. These benchmarks can lead to despair and ultimately depression can have low consensus. Low consensus means that the individual views problems that cause negative events as failures that only occur in him.

High consistency, meaning that failure will always arise when faced with these problems. Finally, a distinguishing power that is easily interpreted as the belief that failure will always occur in the face of other problems.

\section{THE ROLE OF GUIDANCE AND COUNSELING IN THE INTERVENTION OF HOPELESSNESS OF NARAPIDANA WOMEN}

Guidance and Counseling (BK) is not only in school but also outside the school. With the guidance of counseling outside of school can help the community in overcoming various kinds of problems it faces, especially in the Correctional Institution (Lapas) specifically for female prisoners who experience hopelessness.
Guidance and Counseling (BK) plays an important role in dealing with women prisoners who hopelessness ( despair). Because despairing individuals feel that there is no hope anymore, unable to rise again. Desperation is part of a person's thought process, where he has a view or assessment, that he can not do anything else. Even nothing he could hope for. He rated himself too low and always thought negatively. He felt useless, or no one paid attention and no one cared. $\mathrm{M}$ aka here it needs guidance and guidance for inmates so as not to drag on the problem.

To help individuals who have a desperate condition, then it takes the ability to motivate good, and able to develop a sense of confidence in individuals $d$ natural this case the counselor can provide a variety of guidance and counseling services, such as information services, content mastering services, guidance groups, and others (Afdal, 2015; Ernawati \& Afdal, 2019; Hasanah, Ilyas, \& Afdal, 2018). With this relationship, the problems experienced by the counselee will be examined and their alleviation will be worked out with the client's own strength (Prayitno \& Erman, 2015). With this service the counselor can listen to female prisoners in presenting the various problems they face and feel by showing empathy so that the client does not hesitate, fear, worry about delivering them. The problems that have been conveyed can be identified and given direction to increase their motivation so that they can have hope and continue to live a better life.

Group guidance service is a Guidance and Counseling (BK) service that allows several female prisoners together through group dynamics to discuss various things that are useful for each group member. In a group, counseling discussed general topics of concern with group members (Prayitno \& Erman, 2015). With this service, it can help female prisoners to express their respective problems regarding hopelessness that they are experiencing in groups and counselors here as group leaders. Where when conducting these service activities the counselor can provide guidance and understanding to prisoners regarding the concept of hopelessness, what are the components of hopelessness, and what factors influence hopelessness.

And information services are services provided together with orientation services with the aim of providing understanding to individuals related to various things needed to carry out tasks and activities, as well as to determine the direction, goals, and things that are desired (Prayitno \& Erman, 2015) This service aims to provide understanding for prisoners who are experiencing hopelessness by providing knowledge and topics on how to communicate well, how to be happy, how to establish a good relationship with the surrounding environment, and how to increase motivation in order to live a better life. Through this understanding and knowledge, female prisoners can make good decisions for themselves in the future.

\section{CONCLUSION}

Hopelessness is a psychological response to negative events, which consists of negative expectations regarding one's future and expectations of powerlessness 
in changing one's future. This despair can be a trait or a condition. Their components despair namely: Affective component (how to feel something), Cognitive component (way of thinking), and Behavioral component (how to act) as well as the attributes of despair are: the experiential process, spiritual/transcendent process, irrational thought process, and relational process that identified in this analysis is the basis for building knowledge relating to the despair of female prisoners.

With the BK service, it can help to follow up on the hopelessness problems of female prisoners and provide better direction so that female prisoner can be motivated and return to normal conditions where the situation is like enthusiasm in carrying out activities and wanting to re-communicate with those around them.

\section{REFERENCES}

[1] Abramson, L. Y., \& Metalsky, G. I. (1989). Hopelessness Depression: A Theory-Based Subtype of Depression, (2), 358-372.

[2] Afdal, A. (2015). Kolaboratif: Kerangka Kerja Konselor Masa Depan. Jurnal Konseling Dan Pendidikan, 3(2), 1. https://doi.org/10.29210/12400

[3] Beck, A. T., Weissman, A., Lester, D., \& Trexles, L. (1974). Measurement of pessismism- Hopelessness Scale. J Consult Clin Psychol, 42(6), 861-865.

[4] Budiman, H. (2017). Rumah Tahanan Negara ( Studi di Lembaga Pemasyarakatan Kelas IIA Kuningan ), 04, 7785.

[5] Caninsti, R. (2012). Penyusunan Skala Keputusasaan untuk Pasien Penyakit Kronis: Studi pada pasien gagal ginjal kronis yang menjalani terapi hemodialisis., 1(1), 44-55.

[6] Carpenito, L. J. (2013). Nurshing diagnosis: Application to clinical practice (14th ed.). Philadelphia, FA: Lippincot Williams \& Wilkins.
[7] Davison, Johson, Kring, N. (2013). Abnormal Psychology: Twelfth Edition. California: University Of California-Los Angeles.

[8] Dunn, S. L. (2005). Hopelessness as a response to physical illness. Journal of Nursing Scholarship, 37(2), 148-154. https://doi.org/10.1111/j.1547-5069.2005.00027.x

[9] Ernawati, R., \& Afdal. (2019). Menggunakan teknik modelling melalui layanan penguasaan konten di SMPN 49 Jakarta pada siswa kelas 8 tahun ajaran 2018-2019. Jurnal Selaras, 1(2), 81-95.

[10] Hasanah, A., Ilyas, A., \& Afdal, A. (2018). Kreativitas Siswa dan Upaya Guru Bimbingan dan Konseling/Konselor dalam Pengembangannya. Insight: Jurnal Bimbingan Konseling, 7(1), 1-8. https://doi.org/10.21009/insight.071.01

[11] Kartono, K. (2003). Patologi Sosial Jilid 1. Jakarta: Grafindo Persada.

[12] Lumenta, C. Y., Kekenusa, J. S., Hatidja, D., Jalur, A., \& Eksogen, V. (2009). Path Analysis Of Factors Cause Crime In Manado.

[13] Nietzel, Speltz, M. ., McCauley, E. A., \& Bernstein, D. . (1998). Abnormal Psychology. Boston: Allyn \& Bacon.

[14] Prayitno\&, \& Erman, A. (2015). Dasar-Dasar Bimbingan dan Konseling. Jakarta: Rineka Cipta.

[15] Puspasari, D. (2016). Efektifitas terapi kognitif perilaku dalam kelompok untuk menurunkan depresi narapidana wanita di lapas klas iia muaro padang.

[16] Sullivan, M. D. (2003). Hope and hopelessness at the end of life. American Journal of Geriatric Psychiatry, 11(4), 393-405. https://doi.org/10.1097/00019442-20030700000002

[17] Tololiu, T. A., \& Makalalag, H. (2015). Hubungan Depresi Dengan Lama Masa Tahanan Malendeng Manado, 4. 